\title{
Detection of 2, 4-D in groundwater in northeast of the Yucatan Peninsula
}

\section{Detección de 2, 4-D en agua subterránea en el noreste de la Península de Yucatán}

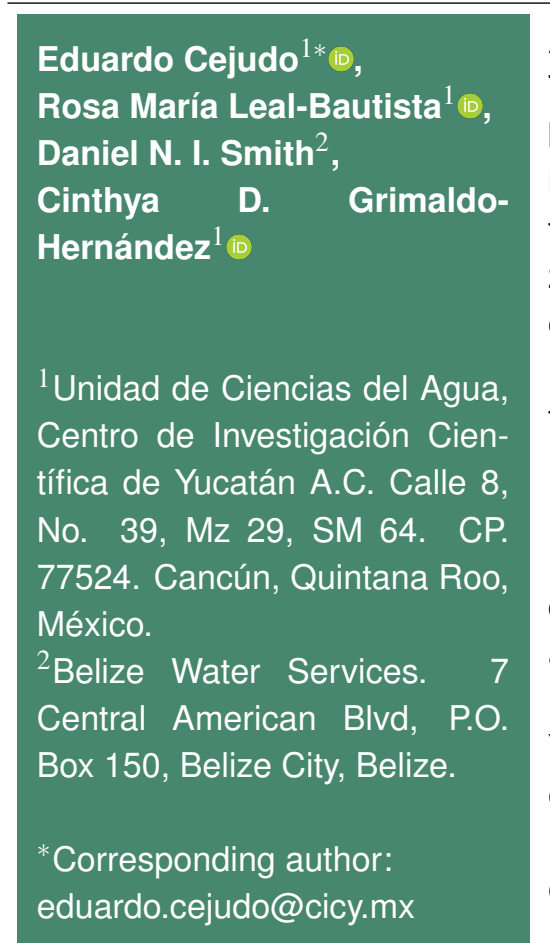

Scientific note

Received: december 04, 2019

Accepted: april 06, 2021

How to cite: Cejudo E, Leal-Bautista RM, Smith DNI, Grimaldo-Hernández

(2021) Detection of 2, 4-D

in groundwater in northeast

of the Yucatan Peninsula.

Ecosistemas y Recursos

Agropecuarios 8(1): e2472.

DOI: 10.19136/era.a8n1.2472
ABSTRACT. Herbicides are used to increase the yield of crops and pastures. The herbicide 2, 4-D has high leaching potential in karstic environments because it is water soluble, which causes that the herbicide has been found in groundwater and submerged caves in the Yucatan Peninsula. We detected the presence of the herbicide in groundwater in agricultural non-agricultural zones in the northeaster of the Yucatán Peninsula by using the UV spectrum obtained from HPLC-DAD as qualitative indicator. This finding supports the notion that application of 2, 4-D before and during the wet season promotes the presence of the herbicide in groundwater.

Key words: Agriculture, aquifer contamination, herbicides, HPLC.

RESUMEN. Los herbicidas se usan para aumentar el rendimiento de cultivos y pastos. El herbicida 2, 4-D tiene un alto potencial de lixiviación en ambientes cársticos por ser soluble en agua, lo que provoca que el herbicida haya sido detectado en agua subterránea y cuevas en la Península de Yucatán. En esta nota presentamos resultados de la detección del herbicida en el agua subterránea en zona agrícola y no agrícola en el noreste de la península de Yucatán mediante el uso de espectro UV obtenido con equipo HPLC-DAD como indicador cualitativo de su presencia en el acuífero. Este hallazgo respalda la idea de que la aplicación de 2, 4-D antes y durante la estación de lluvias fomenta la presencia del herbicida en el agua subterránea.

Palabras clave: Agricultura, contaminación del acuífero, herbicidas, HPLC. 


\section{INTRODUCTION}

The use of agrochemicals is aiming to increase crop production; as population increases, so does the demand for agricultural products; therefore, the application of agrochemicals is becoming common practice for achieving larger crop yields (Odegard and Van der Voet 2014). Most commercial agroecosystems apply pesticides at various times of the crop cycle. Herbicides are a group of pesticides used to eliminate weeds from crops in agricultural lands (Ekström and Ekbom 2011). The herbicide 2, 4Dichlorophenoxyacetic acid (2, 4-D) belongs to the phenoxy compounds group; these compounds are potentially toxic to humans causing damage to the nervous system, kidney and liver (Boivin et al. 2005). The 2, 4-D is used to control the growth of broadleaf weeds. It is soluble at $\mathrm{pH}$ close to neutral (National Pesticide Information Center 2008), it remains in the soil from 40 to 60 days (Gaultier and Farenhorst 2007, Gongora-Echeverría et al. 2019). Its degradation varies according to the microbial population and soil pore size among other factors (Kuwatsuka and Miya 1989, Boivin et al. 2005, Trivedi et al. 2015). The herbicide has moderate leaching potential in karst soils (Gongora-Echeverría et al. 2019); therefore, the molecule of 2, 4-D and its degradation products can move into the aquifer, generating residues in groundwater due to its solubility and extended half-life (Caldas et al. 2011). This causes that 2, 4-D can be found in groundwater in karstic areas and it can be used as a tracer of contaminant within agricultural zones, especially in shallow aquifers (Carbo et al. 2008).

Groundwater in the Yucatan Peninsula is vulnerable to contaminants as it is a permeable limestone structure where thin soils are dominant, making the aquifer vulnerable to contamination by the leaching of residues (Bauer-Gottwein et al. 2011, Polanco-Rodriguez et al. 2015, Lorenzo-Flores et al. 2017). Groundwater in this region is the only available fresh water resource; thus, is very important ensuring that concentration of 2, 4-D does not exceed the maximum permissible limit $\left(30 \mu \mathrm{g} \mathrm{L}^{-1}\right)$ in water for human consumption (SS 1994). 2, 4$D$ in the Yucatan Peninsula is mostly used to main- tain short term crop production and the recommended application on pasturelands is $150 \mathrm{mg} \mathrm{2,4-D}$ active ingredient ha ${ }^{-1}$ (INIFAP 2015). Sometimes, application is greater because farmers apply it based on experience on previous effectiveness and aggregated value of crops that requires delicate care (Sanchez et al. 2016).

Pacheco et al. (1997) detected 2, 4-D residues in groundwater wells in Yucatan and Metcalfe et al. (2010) found 2, 4-D at concentrations as high as 10.5 $\mathrm{mg} \mathrm{L}^{-1}$ in submerged caves, attributed to its use in golf courses and gardens throughout touristic centers along the Riviera Maya. In 2000, the European Union classified 2, 4-D as substance that poses adverse health effects; some health risks associated with the exposure of 2, 4-D are possible cases of cancer, skin irritation, respiratory disruption and damage to the endocrine system (Vissers 2005). This note report recent detection of 2, 4-D in groundwater samples from the northeastern Yucatan Peninsula.

\section{MATERIALS AND METHODS}

The study area includes an agricultural area and a non-agricultural area, located in the northeastern Yucatan peninsula (Figure 1). The agricultural area hereby considered, comprises three municipalities of Yucatan (Tizimín, Sucilá and Panabá), the leading producer cattle zone in the state of Yucatan. It has an annual precipitation from 600 to 800 $\mathrm{mm} \mathrm{y}{ }^{-1}$, with a temperature ranging from $22-28{ }^{\circ} \mathrm{C}$. The non-agricultural area comprised the well fields under the concession of the water operating body in the municipality of Benito Juarez (Quintana Roo) with an annual precipitation of $1300 \mathrm{~mm} \mathrm{y}^{-1}$ and annual temperature between $24-28{ }^{\circ} \mathrm{C}$ (INEGI 2017). The geological structure is mainly composed of Neogene and Quaternary platform with sedimentary calcite and leptosols, cambisols and luvisols (INEGI 2009, Bautista et al. 2015).

In 1992, the herbicide 2, 4-D reached an estimated amount of $323 \mathrm{t}$ applied into fields, representing $32 \%$ of the total of pesticides used in the agroindustry (Alvarado-Mejia et al. 2010). According to Gongora Echeverría et al. (2017), the herbicide 2, 


\section{Study Sites (Agricultural Zone and Non-Agricultural Zone)}

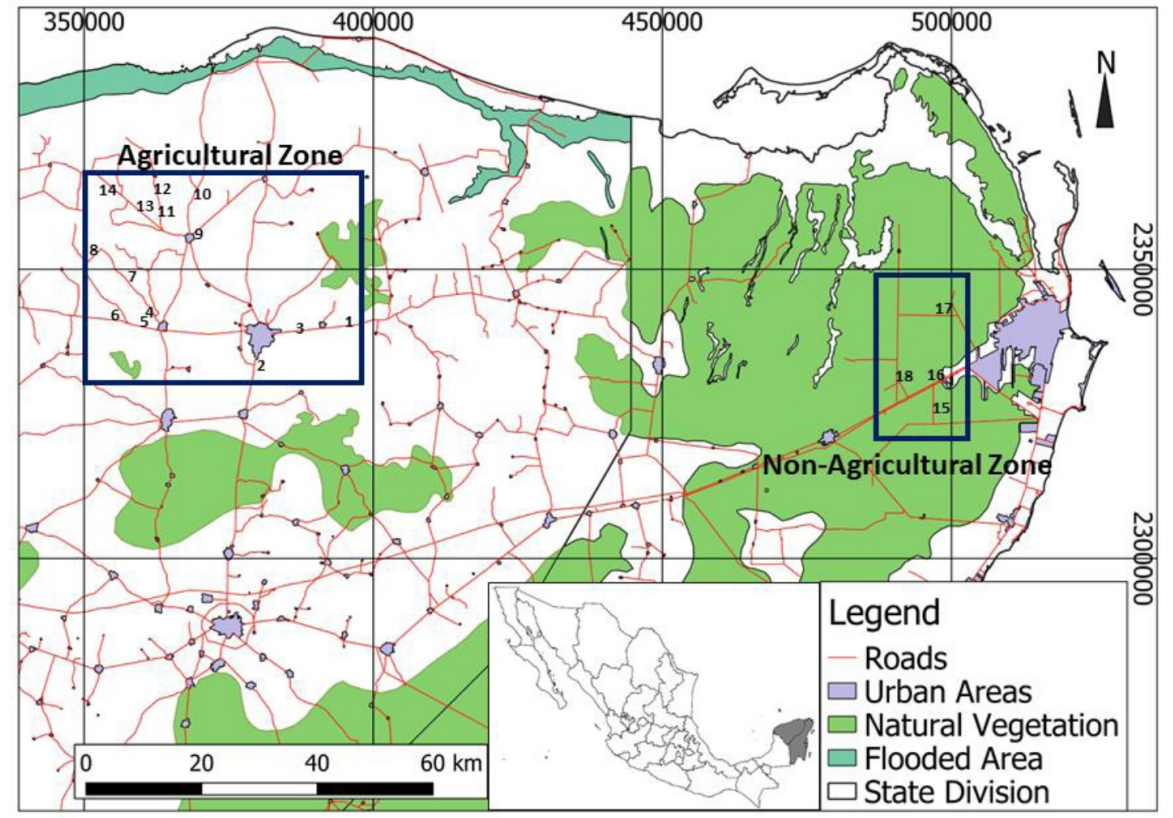

Figure 1. Study area in the Peninsula of Yucatan. Vectorial data form INEGI (2015).

4-D is amply used by farmers in the Yucatan Peninsula. The use of 2, 4-D in Quintana Roo is greater in the south, where sugar cane is produced (Euán-Avila et al. 2002); however, the herbicide is used in golf courses.

Samplings were seasonal, representing cold front (February 2018) and dry seasons (May 2018). We sampled 14 wells in the agricultural zone and four wells in the non-agricultural zone. Wells were selected based on current use for irrigation or water abstraction, not exposed to surface runoff (covered) and within an estimated depth of $12-20 \mathrm{~m}$. Water samples were collected in $500 \mathrm{ml}$ glass amber bottles, previously washed with phosphate-free detergent and rinsed with ethanol and acetone. Water samples were preserved with $\mathrm{H}_{3} \mathrm{PO}_{4}$ at $\mathrm{pH} 3$ and stored at $4{ }^{\circ} \mathrm{C}$ before analyses. Additionally, we applied semi-structured interviews to 10 farmers in each municipality $(n=30)$, in order to acquire information regarding application practices of this herbicide such as the area of the ranch, season of application of herbicide and hours of irrigation per day.
Extraction (SPE) and analysis were performed following Caldas et al. (2010). A 2, 4-D stock soIution (2, 4-D Pestanal 31518, Sigma Aldrich, Lt\# SZBD352XV) was prepared in acetonitrile at a concentration of $1000 \mathrm{mg} \mathrm{L}^{-1}$. Extraction was performed using cartridges Strata C 18-E $\left(55 \mu \mathrm{m}, 70 \mathrm{~A}^{\circ}\right)$, conditioned with methanol $(3 \mathrm{ml})$, followed by washing with Type I water $(1 \mathrm{~mL})$, finally loading $250 \mathrm{~mL}$ of sample. Elution was done with acetonitrile to a final volume of $1 \mathrm{ml}$. Samples were then injected into the HPLC-DAD (Agilent 1290 Infinity, column kromasil $100-5-\mathrm{C} 18,150 \mathrm{~mm}$ length). Mobile phase was $50 \%$ acetonitrile, $30 \%$ methanol, $20 \%$ distilled water at a flow rate of $0.5 \mathrm{ml}$ minute ${ }^{-1}$. Quantification and UV spectra were recorded in 200-210 nm range. With these conditions, the 2, 4-D analytical standard had a retention time of 1.78 min (Figure 2). Blank samples and spiked samples of a commercial formulation (Tordon $101^{\mathrm{R}}$ ) were prepared and analyzed as well. The calibration curve was prepared with five standard concentrations $(1,2.5,5.7 .5$ and $10 \mathrm{mg}$ 2, 4-D $\mathrm{L}^{-1}$ ). The curve equation was $\mathrm{y}=8.28792 \times 10^{-8}$ 


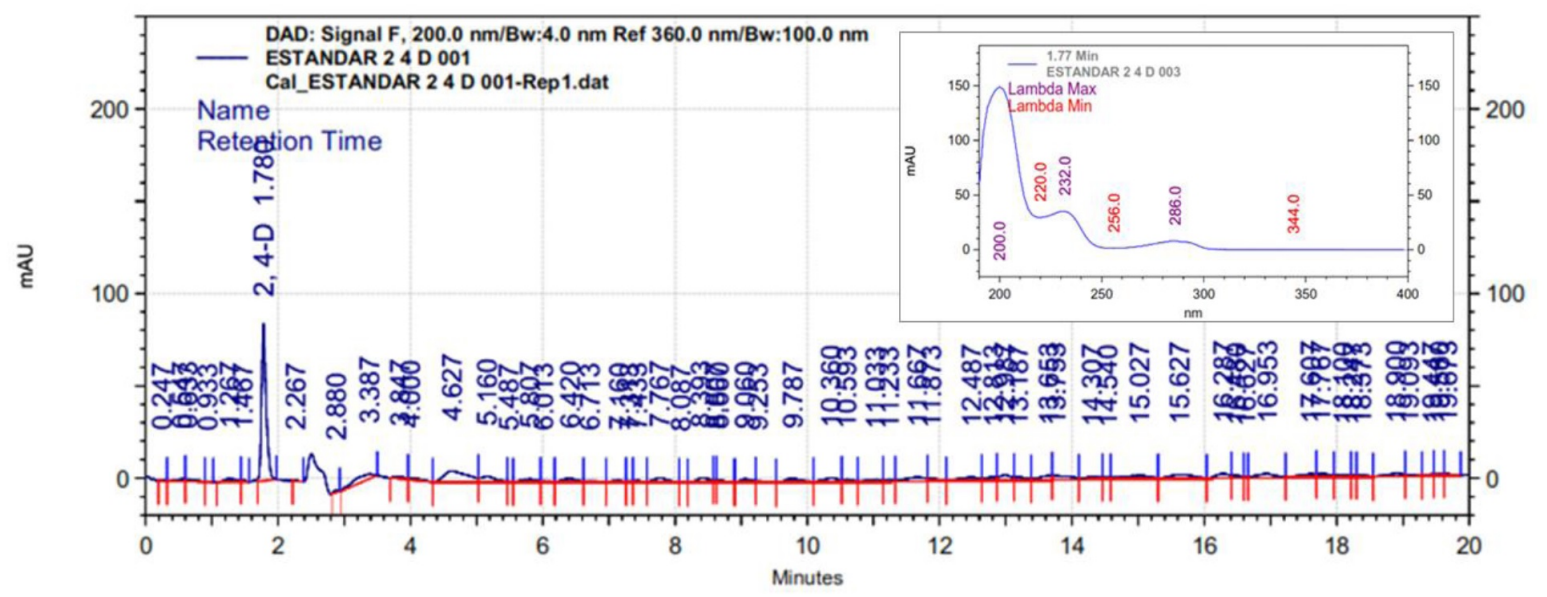

Figure 2. Chromatograph and absorption spectrum of the analytical standard 2, 4-D. Please refer to HPLC-DAD conditions in Section Materials and methods.

$x-3.45848\left(r^{2}=0.99093\right)$; the limit of quantification

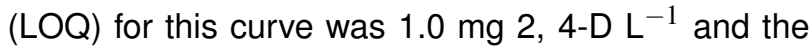
limit of detection (LOD) was assumed as half the detection limit of the lowest standard $(0.5 \mathrm{mg} \mathrm{2,4-D}$ $\left.\mathrm{L}^{-1}\right)$. In cases where peak resolution was poor or

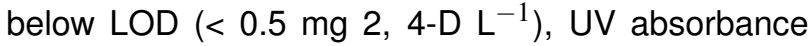
spectra were used as qualitative supporting information regarding the presence of 2, 4-D- herbicide in samples.

\section{RESULTS AND DISCUSSION}

We detected the presence of the herbicide in several samples (Table 1); however, most of them were below detection limit $\left(<0.5 \mathrm{mg} 2,4-\mathrm{D} \mathrm{L}^{-1}\right)$; thus, peak resolution was not optimal and we were not able to integrate an area for quantification (Figure 3). No modifications on the mobile phase were performed and better resolution was not achieved. We use the UV spectra as a qualitative indicator of the presence of the herbicide in the water samples collected.

During the cold front season sampling (February 2018), we obtained evidence of presence of 2, 4-D in three samples in the agricultural zone and one sample in the non-agricultural zone (Table 1). In the dry season (May 2018) five samples from the agricultural zone showed presence of 2, 4-D below quantification limit. In order to compare the commercial formulation Tordon-101 ${ }^{\circledR}$ with our field samples, the spectrum of one spiked sample is showed in Figure 4.

Given that 2, 4-D starts to degrade in the soil between 10 and 60 days and it was found during the cold front season (February), it is possible that the herbicide would have been applied during the postharvesting season, close to the end of the calendar year (November - December). During the interviews, we did not obtain any information regarding application during this season. However, we cannot discard longer persistence due to slower or little degradation. The information acquired during interviews with ranch owners or administrators, recorded that $87 \%$ of farmers use the herbicide Tordon $101 \AA ; 60 \%$ of them pointed to herbicide application before or during the wet season. Applying 2, 4-D to crops before the rain could have implications on contamination of groundwater quality as rain it might cause the deep infiltration of herbicide. During the dry season sampling one site (R. Paraiso) showed physical evidence of empty bottles of herbicides containing 2, 4-D while conducting sampling; thus, suggesting its recent use. (pers.obs.). Detection of a molecule similar to dichlorophenol (2, 4-DCP) in the non-agricultural zone suggests that herbicide use occurred nearby, we can only speculate of herbicide use in the area for weed clearing purposes around the extraction well or roads.

The presence of 2, 4-D in groundwater sam- 
Table 1. Presence of 2, 4-D in the agricultural (A) and non-agricultural (NA) zones during the cold front and dry seasons. Coordinates in UTM units.

\begin{tabular}{|c|c|c|c|c|}
\hline Land use & ID & Site & Season & Concentration \\
\hline \multirow{9}{*}{$\begin{array}{l}\overline{\bar{\sigma}} \\
\frac{3}{3} \\
\frac{ \pm}{5} \\
. \frac{0}{5} \\
\frac{5}{4}\end{array}$} & 1 & INIFAP & n.d. & \\
\hline & 2 & Rancho Yokdzonot & Cold Front & 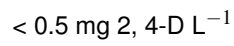 \\
\hline & 3 & Rancho Las Trancas & Dry & 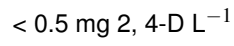 \\
\hline & 4 & Rancho Paraíso & Dry & 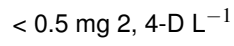 \\
\hline & 5 & Rancho San Gabriel & n.d. & \\
\hline & 6 & Rancho San Pedro & Dry & 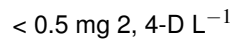 \\
\hline & 7 & Rancho Justo Juez & Cold Front & 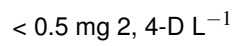 \\
\hline & 8 & Rancho San Gabino & Dry & 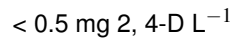 \\
\hline & 9 & Rancho San Francisco & n.d. & \\
\hline \multirow{9}{*}{ 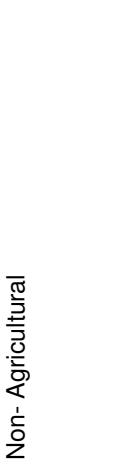 } & 10 & Rancho San Francisco 2 & n.d. & \\
\hline & 11 & Rancho Cristal & Dry & 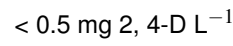 \\
\hline & 12 & Rancho Bendición de Dios & Cold Front & 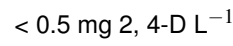 \\
\hline & 13 & Rancho de Los Conde & n.d. & \\
\hline & 14 & Rancho Santa Rosa & n.d. & \\
\hline & 15 & ZC1P4 & n.d. & \\
\hline & 16 & ZC2P11 & n.d. & \\
\hline & 17 & ZC4P11 & n.d. & \\
\hline & 18 & ZC5P1 & Cold Front & 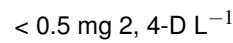 \\
\hline
\end{tabular}

ples suggests that water infiltrates at a local scale, and that water likely mobilize several dissolved substances (agrochemicals included) as a result of irrigation or after precipitation. Mikesell and Boyd (1985) found that most rapid degradative reaction observed in 2, 4-D was removal of $\mathrm{Cl}$ atoms, yielding dichlorophenol as the first stable degradation product in aqueous solution (Oturan 2000). Since the herbicides and some degradation products (metabolites or by-products) have been found in groundwater (Pinheiro et al. 2010, McManus et al. 2014), it is possible that some of these compounds are present in the aquifer. Metabolites and by-products such as chlorophenols can result from water potabilization (Czaplicka 2004); yet, we do not consider that this is the case in production wells region because chlorination is made in pumping stations after extraction. It is important to monitor such possibility given that chlorination is the main disinfection practice in Quintana Roo for water potabilization; further research is needed regarding detection and quantification of metabolites and by-products of 2, 4-D in the Yucatan Peninsula such as adsorption and retention of herbicides in the soil and the use of Liquid Chromatography Mass Spectrometry (LC-MS) for accurate results.

Soil microbiota helps to increase degradation in the soil (Serbent et al. 2019); it is likely that degradation in groundwater occurs at a different rate. 2, 4-D residues are usually associated with organic matter, which makes it prone to degradation by microbes (Trivedi et al. 2015, Botero et al. 2017). Given the residence time of 2, 4-D in the environment (as long as 90 days) and the fact that photodegradation is the most important degradation processes of chlorophenols in the environment (Czaplicka 2004), the detection of the herbicide or degradation products serve as an indicator of recent introduction of pesticides into the aquifer, polluting the water at a local scale. Timely and efficient application of herbicides will reduce the risk of groundwater contamination; for instance, apply 


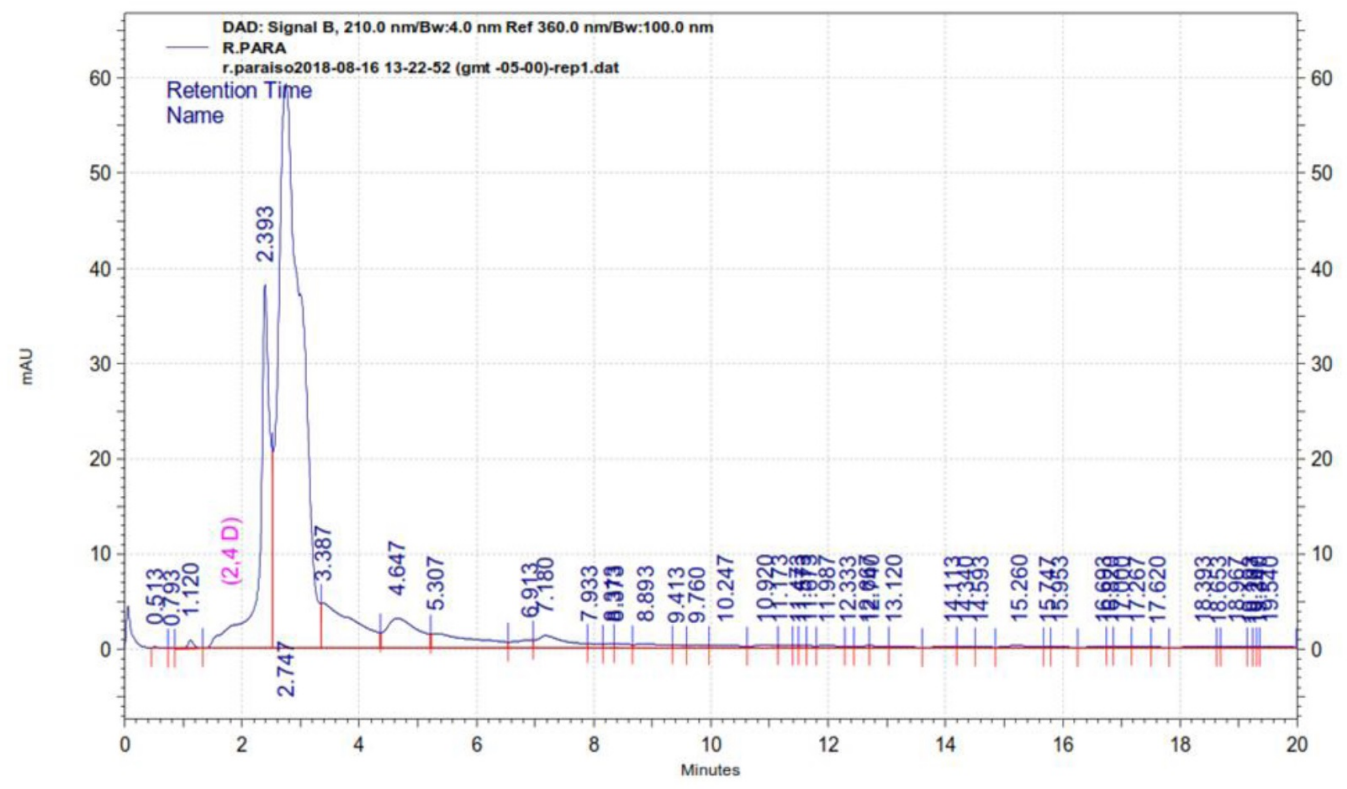

Figure 3. Chromatograph of agricultural sampling site (R. Para; 362983, 2340418) collected in May 2018 showing detection of 2, 4-D but with resolution not suitable for quantification (missing area integration).
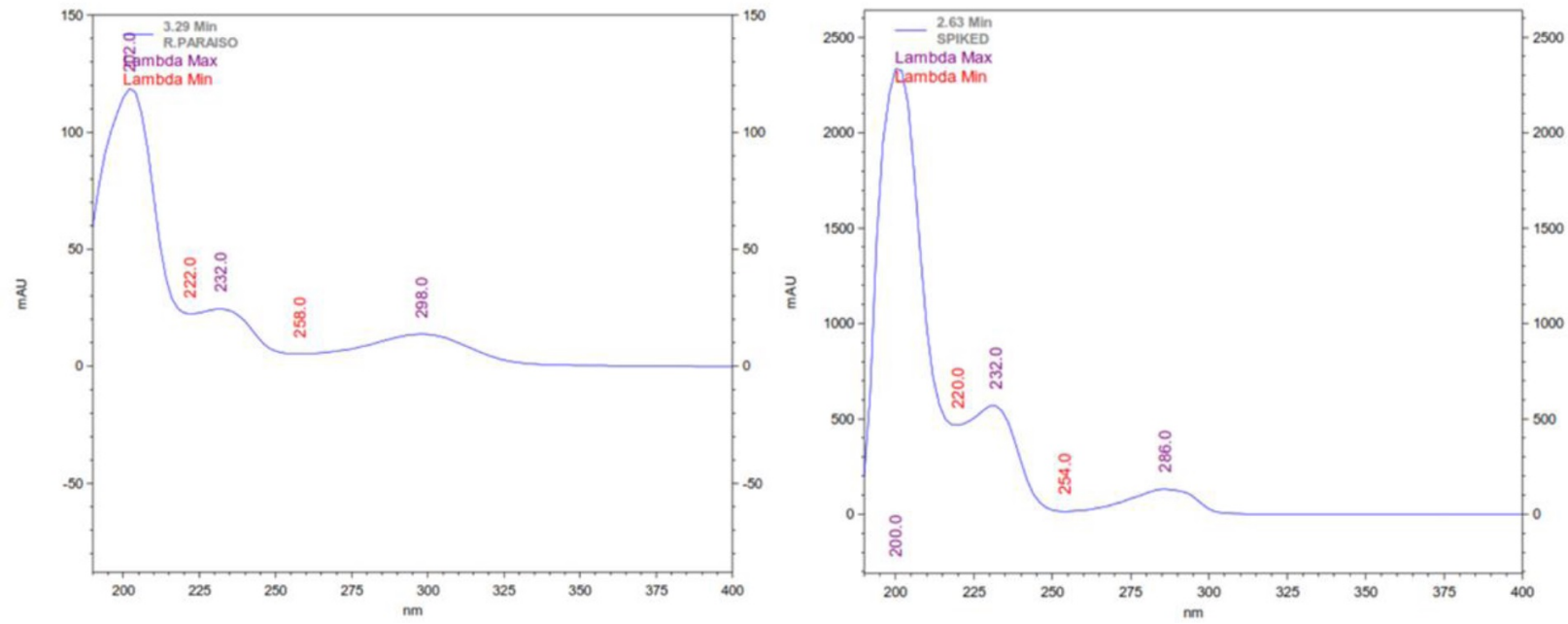

Figure 4. Absorption spectrum of a sample from the agricultural zone (R. Paraiso, left) showing similarity to the spiked sample with the commercial formulation Tordon $101^{\circledR}$ spectrum (right).

when there is minimum risk for runoff or aerial losses (Baird et al. 2000). Method of application must consider the type of soil and its properties because its thickness, mineral and textural composition are indicators of the feasibility of retention or infiltration of the herbicide and might regulate the amount of substance potentially remaining in the soil and the proportion of the active ingredient that could infiltrate to groundwater (Boivin et al. 2005).
In conclusion, we detected herbicide 2, 4 in groundwater in the northeastern Yucatan peninsula at concentrations lower than $0.5 \mathrm{mg} 2,4-\mathrm{D} \mathrm{L}^{-1}$, most prevalent in the agricultural zone in both dry and cold front seasons. Good land management strategies and water quality monitoring are needed in agricultural zones as pesticides mobilization is impacting groundwater quality. 


\section{LITERATURE CITED}

Alvarado Mejía JA, Gonzalez Navarrete L, Perez-Herrera ME (2010) Exposición a plaguicidas organofosforados y carbamatos en agricultores de Yucatán y sus efectos en la salud. En: Jimenez Delgadillo BMG, Vado Solís IA, Alvarado Mejia A, Gonzalez Navarrete L (eds.) Aportes al Conocimiento de la salud en Yucatán. UADY. México. p: 229-245.

Baird JH, Basta NT, Huhnke RL, Johnson GV, Payton ME, Storm DE, Wilson CA, Smolen MD, Martin DL, Cole JT (2000) Best management practices to reduce pesticide and nutrient runoff from turf. In: Clark JN, Kenna MN (eds.) Fate and management of turfgrass chemicals. ACS Symposium Series Vol. 743. USA. 16: 268-293.

Bauer-Gottwein P, Gondwe BN, Charvet G, Marín LE, Rebolledo-Vieyra M, Merediz-Alonso G (2011) Review: The Yucatán Peninsula karst aquifer, Mexico. Hydrogeology Journal 19: 507-524.

Bautista F, Frausto O, Ihl T, Aguilar Y (2015) Actualización del mapa de suelos del Estado de Yucatán México: Enfoque geomorfopedológico y WRB. Ecosistemas y Recursos Agropecuarios 2: 303-315.

Boivin A, Amellal S, Schiavon M, Genuchten MT (2005) 2, 4-Dichlorophenoxyacetic acid (2, 4-D) sorption and degradation dynamics in three agricultural soils. Environmental Pollution 138: 92-99.

Botero LR, Mougin C, Peñuela G, Barriuso E (2017) Formation of 2, 4-D bound residues in soils: New insights into microbial metabolism. Science of the Total Environment 584: 715-722.

Caldas SS, Demoliner A, Costa FP, D'Oca MG, Primel EG (2010) Pesticide residue determination in groundwater using solid-phase extraction and high-performance liquid chromatography with diode array detector and liquid chromatography-tandem mass spectrometry. Journal of the Brazilian Chemical Society 21: 642-650.

Caldas SS, Zanella R, Primel E (2011) Risk estimate of water contamination and occurrence of pesticide in the South of Brazil. In: Kortekamp A (ed) Herbicides and environment. In Tech. Croatia. pp: 471-492.

Carbo L, Souza V, Dores EF, Ribeiro ML (2008) Determination of pesticides multiresidues in shallow groundwater in a cotton-growing region of Mato Grosso, Brazil. Journal of the Brazilian Chemical Society 19: 1111-1117.

Czaplicka M (2004) Sources and transformations of chlorophenols in the natural environment. Science of the Total environment 322: 21-39.

Ekström G, Ekbom B (2011) Pest control in agro-ecosystems: an ecological approach. Critical Reviews in Plant Sciences 30: 74-94.

Escolero O, Marín L, Steinich B, Pacheco J, Maldonado A, Anzaldo J (2005) Geochemistry of the hidrogeological reserve of Mérida, Yucatan, Mexico. Geofisica International 44: 301-314.

Euán-Ávila Jl, Liceaga-Correa MN, Rodríguez Sánchez H (2002) Caracterización de fuentes no puntuales de contaminación agrícola en el municipio de Othón P. Blanco en Quintana Roo, y su potencial influencia en la Bahía de Chetumal. En: Rosado-May F, Romero Mayo R, De Jesús Navarrete A (eds.) Contribuciones de la ciencia al manejo costero integrado de la Bahía de Chetumal y su área de influencia. Universidad de Quintana Roo, México. pp: 197-204.

Gaultier J, Farenhorst A (2007) 2, 4-D Mineralization in soil profiles of a cultivated hummocky landscape in Manitoba, Canada. Journal of Environmental Science and Health, Part B 42: 255-264.

Góngora-Echeverría VR, Martin-Laurent F, Quintal-Franco C, Lorenzo-Flores A, Giácoman-Vallejos G, PonceCaballero C (2019) Dissipation and Adsorption of 2, 4-D, Atrazine, Diazinon, and Glyphosate in an Agricultural Soil from Yucatan State, Mexico. Water, Air, \& Soil Pollution 230: 131 Doi: 10.1007/s11270-019-4177-y 
INEGI (2009) Prontuario de Información Geográfica Municipal de los Estados Unidos Mexicanos. Instituto Nacional de Estadística y Geografía. México. http://www3.inegi.org.mx/contenidos/app/mexicocifras/datos_ geograficos/31/31096.pdf. Date consulted: 22 march, 2021.

INEGI (2017) Anuario estadístico y geográfico de Quintana Roo. Instituto Nacional de Estadística y Geografía. México. 408p.

INIFAP (2015) Agenda Técnica Agrícola YUCATAN. Progreso, Yucatán, México. 135p.

Kuwatsuka S, Miya N (1989) Change in Population of 2, 4-D Degraders in the Process of 2, 4-D Degradation in Soils under Upland and Flooded Conditions. Soil Science and Plant Nutrition 35: 535-543.

Lorenzo-Flores A, Giácoman-Vallejos G, Ponce-Caballero MC, Hossein G (2017) Adsorption of organophosphorus pesticides in tropical soils: The case of karst landscape of northwestern Yucatan. Chemosphere 166: 292-299.

McManus SL, Moloney M, Richards KG, Coxon CE, Danaher M (2014) Determination and occurrence of phenoxyacetic acid herbicides and their transformation products in groundwater using ultra high performance liquid chromatography coupled to tandem mass spectrometry. Molecules 19: 20627-20649.

Metcalfe C, Beddows P, Bouchot G, Lavieren V (2010) Contaminants in the coastal aquifer system along the Caribbean coast of the Yucatan Peninsula. Environmental Pollution 159: 991-997.

Mikesell MD, Boyd SA (1985) Reductive Dechlorination of the Pesticides 2, 4-D, 2, 4,5-T, and Pentachlorophenol in Anaerobic Sludges. Journal of Environmental Quality 14: 337-340.

NPIC (2008) 2, 4-D General fact sheet. Health and environment. National Pesticide Information Center http://npic. orst.edu/factsheets/archive/2,4-DTech.html. Date consulted: 12 november, 2019.

SS (2000) NOM-127-SSA1-1994 Norma Oficial Mexicana Salud ambiental, agua para uso y consumo humanolímites permisibles de calidad y tratamientos a que debe someterse el agua para su potabilización. Secretaria de Salud. Mexico. http://www.salud.gob.mx/unidades/cdi/nom/127ssa14.html. Date consulted: 22 march, 2021.

Odegard IYR, Van der Voet E (2014) The future of food - Scenarios and the effect on natural resource use in agriculture in 2050. Ecological Economics 97: 51-59.

Oturan MA (2000) An ecologically effective water treatment technique using electrochemically generated hydroxyl radicals for in situ destruction of organic pollutants: Application to herbicide 2, 4-D. Journal of Applied Electrochemistry 30: 475-482.

Pacheco SJ, Cabrera SA, Marin LE (1997) Nitrate and 2, 4-D herbicide in the Karst Aquifer of Yucatan, Mexico. In: American Institute of Hydrology (ed). International Conference on Advances in Groundwater Hydrology. pp: 47-51.

Pinheiro A, Silva MR, Kraisch R (2010) Presença de pesticidas em águas superficiais e subterrâneas na bacia do Itajaí, SC. REGA 7: 17-26

Polanco-Rodríguez AG, Navarro-Alberto J, Solorio-Sánchez J, Mena-Rejón G, Marrufo Gómez J, Del Valls CasiIlas TA (2015) Contamination by organochlorine pesticides in the aquifer of the Ring of Cenotes in Yucatán, México. Water and Environment Journal 29: 140-150.

Sanchez J, Alvarez T, Pacheco J, Carrillo L, González RA (2016) Groundwater Quality: Quintana Roo, Mexico, Southern Aquifer. Tecnología y Ciencias del Agua 7: 75-96. 
Serbent MP, Rebelo AM, Pinheiro A, Giongo A, Tavares LBB (2019) Biological agents for 2, 4-dichlorophenoxyacetic acid herbicide degradation. Applied microbiology and biotechnology 103: 5065-5078.

Trivedi MK, Branton A, Trivedi D, Nayak G, Singh R, Jana S (2015) Studies on physicochemical properties of biofield treated 2, 4-dichlorophenol. American Journal of Environmental Protection 4: 292-299.

Vissers M (2005) Patterns of groundwater quality in sandy aquifers under environmental pressure. Netherlands Geographical Studies No. 335. Utrecht University. Netherlands. 144p. 